ENTREPRENEURSHIP AND SUSTAINABILITY ISSUES

ISSN 2345-0282 (online) http://jssidoi.org/jesi/ 2019 Volume 7 Number 1 (September)

http://doi.org/10.9770/jesi.2019.7.1(39)

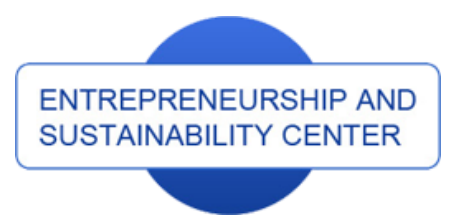

Publisher

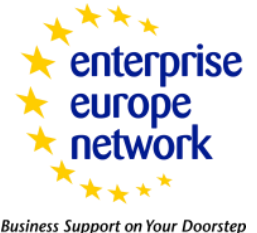

CASPA S

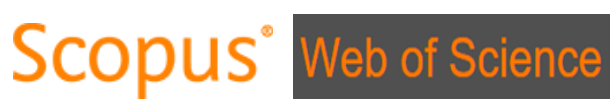

http://jssidoi.org/esc/home

\title{
MILITARY EXPERIENCED BOARD AND CORPORATE SOCIAL RESPONSIBILITY DISCLOSURE: AN EMPIRICAL EVIDENCE FROM INDONESIA*
}

\author{
Mohammad Nasih¹, Iman Harymawan*2, Fajar Kristanto Gautama Putra ${ }^{3}$, Rizka Qotrunnada ${ }^{4}$ \\ 1,2,3,4 Universitas Airlangga, Airlangga No. 4-6, Surabaya, 60286, Indonesia \\ E-mails: ${ }^{1}$ mohnasih@feb.unair.ac.id; ${ }^{2 *}$ harymawan.iman@feb.unair.ac.id (corresponding author); \\ ${ }^{3}$ fajar.kristanto@akuntanindonesia.or.id; ${ }^{4}$ rizka.qotrunnada@gmail.com
}

Received 13 February 2019; accepted 20 July 2019; published 30 September 2019

\begin{abstract}
This study examines the impact of military connection and politically connection on Corporate Social Responsibility Disclosure. Using 110 firm year observations of Indonesia listed firms, we predict that the presence of military or politically connection in firm's board will increase the Corporate Social Responsibility Disclosure level on its Sustainability Report. We found that military connected boards increase the Corporate Social Responsibility Disclosure while politically connection does not show any correlation. Our further analysis on specific type of each connection shows that military career position, army military origin, marine military origin, People's Consultative Assembly politically affiliation and House of Representation politically affiliation increase the level of Corporate Social Responsibility Disclosure level. Our result is robust due to various research model and Heckman's two stage regression.
\end{abstract}

Keywords: corporate social responsibility disclosure; military connection board; politically connected board

Reference to this paper should be made as follows: Nasih, M.; Harymawan, I.; Putra, F.K.G.; Qotrunnada, R. 2019. Military experienced board and corporate social responsibility disclosure: an empirical evidence from Indonesia, Entrepreneurship and Sustainability Issues 7(1): 553-573. http://doi.org/10.9770/jesi.2019.7.1(39)

JEL Classifications: M500; Q560

\footnotetext{
* This research has received funding from the Tahir World Class Professorship
} 


\section{ENTREPRENEURSHIP AND SUSTAINABILITY ISSUES}

ISSN 2345-0282 (online) http://jssidoi.org/jesi/

2019 Volume 7 Number 1 (September)

http://doi.org/10.9770/jesi.2019.7.1(39)

\section{Introduction}

For a long time, the military has been viewed as developing value systems and beliefs in its veterans and their potentially great value in corporate business (Elder, 1986; Elder \& Clipp, 1989; Groysberg, Hill, \& Johnson, 2010). Through its influence, a military connection has been of considerable interest in business research topics. This paper adds to the literature by examining the military connection influence towards Corporate Social Responsibility Disclosure (CSRD).

Various studies have examined the influence of military connections towards corporate outcomes. Using 1,115 CEOs with military connection of US Firms, Benmelech and Frydman (2015) found that military-connected CEOs tend to have lower investment and RnD expenses and their firm is less likely to involve in fraud. They also found that military-connected CEOs performed better in industry distress times. Harymawan (2018) found that military-connected firms are statistically proven to have a lower interest rate of loan in Indonesian firms. In order to deal with endogeneity problems, Heckman's two-stage procedures are used in Harymawan's (2018) research. Military experienced CEOs also show has higher announcement-period of abnormal stock returns during corporate acquisition (Lin, et al., 2011). They also document poor corporate governance and acquisition outcomes' negative correlation is weakened by military-connected CEOs presence.

The military connection also shows some implications on corporate tax avoidance. Based on an assumption whereby CEOs who have greater respect for rules will avoid less tax, Law andMills (2013) found that those CEOs which represented as ex-military personnel will lead towards lower corporate tax avoidance, both in cash and GAAP effective tax rate. Further, they researched the detail on CEOs military experiences correlation with tax avoidance by moderating it according to his/her military service length, military academy attendance and having served during World War II, Korean War and Vietnam War (Law \& Mills, 2014). In the latest literature, using a new econometric technique that disentangles manager effects from firm effects, Law and Mills (2017) found CEOs with military experiences maintain lower reserves for unrecognized tax benefits.

Prior literature provides lights on the debate regarding the benefits of hiring a corporate board that has a militaryconnection (Benmelech \& Frydman, 2015; Duffy, 2006; Lin, et al., 2011; Mietzner \& Misol, 2012; Rieffel \& Pramodhawardani, 2007). However, to the as researchers' knowledge, there are no studies that specifically examine the military connection on Corporate Social Responsibly Disclosure (CSRD). Therefore, we focus on examining the correlation of military-connected firms on CSRD to provide additional knowledge of militaryconnected board benefits on the firm.

All samples consisted of Indonesian listed companies, a developing nation where its government has lack of transparency and is inefficient (Leuz, et al., 2003; Porta, et al., 1997), which provides additional opportunity to establish a strong mutual business relationship (Harymawan, 2018). It indicates that political connection is also an important variable to provide a robust result as we examine the correlation of military connection towards CSRD, as political connection shares some similar characteristics with a military connection in terms of the mutual business relationship in developing countries. Prior studies results show that political connection is shown to have a positive correlation with CSRD (Abd Rahman \& Ku Ismail, 2016; Huang \& Zhao, 2016). This correlation is based on political rent extraction (McChesney, 1987), where corporates with a politically-connected board are paid in the form of CSRD to meet government needs as they accept preferential policies from the government.

For our empirical tests, we employ univariate and multivariate analysis to test the hypotheses. Financial firms are excluded from the sample. Our final sample consists of 110 observations from the 2013-2017 period. We also provide additional analysis which is examining several military connections and political connection types to further highlight the relationship between military connection to CSRD. Lastly, we conduct Heckman's two-stage 


\section{ENTREPRENEURSHIP AND SUSTAINABILITY ISSUES}

ISSN 2345-0282 (online) http://jssidoi.org/jesi/

2019 Volume 7 Number 1 (September)

http://doi.org/10.9770/jesi.2019.7.1(39)

regression to deal with the endogeneity problem of military connection with its instrumental variable, which is a military base distance to a firm's headquarter office.

Our empirical results can be summarized as follows. First, we find that military connections are positively and significantly correlated with CSRD. This indicates that firms with rules concerning boards which represented a military connection provide more CSRD. This is because military personnel have a high concern about humanity as they are commonly dispatched to natural disaster sites. We also found that R2 coefficient increases if the military connection is included in the research model. Second, we find that there is no relationship between politically-connected firms and CSRD. One of the possible reasons is the tendency of politically-connected firms to protect the benefits acquired from the political connection (Chaney, et al., 2011), including CSRD.

Additional analysis of specific military and political connection types shows an interesting result. We document that higher military position, army military origin, and marine military origin have a positive significant correlation with CSRD, while, on the other hand, police origin has a negative correlation. This result derives from including Badan Intelijen Nasional (National Intelligence Agency) in police origin, wherein most of their operations are classified so their work nature is carried over into a firm's disclosure level, including CSRD. As for specific political connection types, we found that People's Consultative Assembly (PCA) and House of Representatives (HOR) affiliation has a positive correlation with CSRD. The underlying reason behind the result is that both PCA and HOR are Indonesian government bodies entitled to devise national regulations, including regulation related to CSR activities or its disclosure. Our Heckman's two-stage regression result provides additional empirically robust evidence of correlation of military connection and CSRD.

This study makes several contributions to the literature. First, the result of this study shows the advantages enjoyed by military-connected firms in developing countries (Harymawan, 2018; Mietzner \& Misol, 2012). To our knowledge, this study is the first empirical study to provide the effect of military experience director with a focus on CSRD in Indonesia. Second, this study complements the prior studies in the CSRD (e.g. Cheng, et al., 2014; El Ghoul, et al., 2011; Saeidi, et al., 2015) by providing evidence on the factors that might affect the level of CSRD in developing countries.

The rest of the paper is organized as follows. Section II provides a background for the study and this is followed by the hypotheses development section. Section III describes our sample and research model. Section IV reports our main empirical results. Section V concludes.

\section{Theory and Hypothesis Development}

\subsection{Board Connections Charateristic in Indonesia}

Developing countries (Malaysia, South Africa, Pakistan, Libya, Turkey, etc.), including Indonesia, have provided certain advantages towards firms which select a board that has certain connections (Abd Rahman \& Ku Ismail, 2016; Fung, et al., 2015; Funnel, 2005; Habib, et al., 2017; Harymawan, 2018; Shah, 2014. This results from Indonesia not having strict and detailed regulation on specific board connection characteristics. As long as it does not violate the laws and provides certain benefits, firms will keep considering hiring board(s) that have military and/or political connections.

Military forces (Tentara Nasional Indonesia, TNI) were a dominant player in the economy during the strongman era of President Soeharto, a former general, gaining favored access to contracts and controlling nationalized companies. This phenomenon can be proven to be true as there has always been at least one presidential candidate that has applied in a presidential election since 2004. Thus, we can conclude that Indonesia is a country with an enormous influence of the military over the political decision-making process (Harymawan, 2018). 


\section{ENTREPRENEURSHIP AND SUSTAINABILITY ISSUES}

ISSN 2345-0282 (online) http://jssidoi.org/jesi/

2019 Volume 7 Number 1 (September)

http://doi.org/10.9770/jesi.2019.7.1(39)

After the fall of Soeharto, Indonesia has demonstrated significant progress in the context of the first generation of military reforms, which is closely related with institutional changes in the government security sector (Mietzner, 2009). According to Cottey, et al. (2001), "the first generation" is the important stage where disassembling old power structures and, at the same time, also the definition of what the final goal of the democratic transition should be. Large extraction has been happening in the military from formal politics and business and has developed a new system in legislation in order to overview and control the military. But Indonesia is still trapped and cannot fully enter the second generation of military reform, which is completing the framework that was developed in the first: it provides the democratic substance to the structures established by laws and political decisions (Mietzner, 2009).

In mid-2005, Indonesia established the TNI Business Transformation Management Agency with a primary objective to clean up military business from the Suharto legacy (Vestergaard, 2006), and we documented several examples of businesses that had a major military player involved. A large number of military were involved in business in Indonesia due to the Indonesia military forces raising money outside the government budget by spreading the business network. Such business is not directly controlled by the military's central command, but they have been allowed to spread so as to overcome the budget constraints (Human Rights Watch, 2006).

Undoubtedly, the military has a major influence on Indonesian business, as both parties enjoy mutual benefits. It provides unique institutional settings to examine the relationship between military connection and business activities in Indonesia. Especially the corporate action that relates to certain military traits such as empathy to social situations.

In accordance with a military connection, the political connection is also widely spread in Indonesian business. Indonesia's political party funding system $=$ is basically from three sources - internal (member contributions), state-grant, and external (Mietzner, 2015). The central level of a political party needs approximately 50 billion Rupiahs (\$26 million) funding annually while both member donations and state donations each only 0.6 billion Rupiahs (Faisal, et al., 2018). Thus, it means politics is highly involved in the business as its main source of funds comes from the private sector. On the other side, a business can provide easiness related to specific regulations as its token of gratitude.

\subsection{Hypothesis development}

Military personnel have the impression that they are powerful and disciplined figure that can hopefully give influence in the form of positive corporate actions. Military-connected CEOs can influence executives' decisions, corporate policy, corporate outcomes and tend not to be involved in fraud (Benmelech \& Frydman, 2015). According to Lin, Ma, Officer, and Zou (2011), a military-connected CEO can influence the firm value by lowering the agency cost in the context of acquisition and earn a good acquisition.

Another trait that becomes a main advantages of using ex-military personnel is leadership. Multi-national companies such as Wal-Mart and General Electric are craving leadership talent. Those companies have for some years been recruiting junior military officers that served in Iraq and Afghanistan (O'Keefe, 2010). A major player in business needs a CEO that has already proven they can manage a fiercely competitive business environment and, among all candidates' background, military experiences may well suit best for this requirement (Duffy, 2006). Firms should be interested in appointing directors who possess not only superior decision-making skills under pressure, but who also may be inclined to behave more ethically to prevent future breaches of stakeholder trust (Simpson \& Sariol, 2018). Somehow military personnel have been viewed as a great leader as they have already experienced hard times and rallied the morale of their comrades. Military officers are used to managing the psychology of his/her subordinates to accomplish their duty effectively and efficiently. 


\section{ENTREPRENEURSHIP AND SUSTAINABILITY ISSUES}

ISSN 2345-0282 (online) http://jssidoi.org/jesi/

2019 Volume 7 Number 1 (September)

http://doi.org/10.9770/jesi.2019.7.1(39)

Military personnel have been acknowledged as having a strong relationship with leadership. General Eric K. Shinseki, Chief of Staff of The Army states: "We are about leadership; it is our stock in trade, and it is what makes us different". The military is often stereotyped as a monolithic society and that everything inside the military is homogeneous. Military forces tend to have a diverse collection, such as organizations, roles, cultures, and people (Wong, et al., 2003). For example, in Indonesia, the military is divided into three professions: Angkatan Darat (Army), Angkatan Laut (Marine), and Angkatan Udara (Airforce). Each profession has own uniqueness and culture, and, as a result, its own unique aspect of leadership.

Military personnel are also known as parties used to being the first backup to help causalities when there is a disaster. As military personnel are often to be dispatched as soon as possible to a disaster location, it's possible to foster military personnel sensitivity towards society conditions through various humanity actions which are closely related to Corporate Social Responsibility (CSR).

Oh, Bae, \& Kim (2017) claim that sinful firms which including firearms and military industries tend to neutralize their negative image by intensifying advertising of their CSR activities. According to them, sinful firms tend to increase advertising efforts when they engage in CSR comparing to non-sinful firms. It can be hint for management of military industries who also mostly military veterans are used to view CSR as important variable to maintain firms' image.

The combined traits that we previously mentioned will ensure military personnel will encourage the other management to follow his/her opinion, resulting in companies having tendencies to pay more attention to their CSR activities. Those CSR activities will be documented in the company's Sustainability Report (SR) and, as a result, military-connected companies indicate their CSE as one of the important corporate actions that needs to be done. For all those reasons we devise the first hypothesis as follow:

\section{H1: Military-Connected Board is positively related to CSRD}

Political connections allow a company to be able to increase economic benefits and some companies have a more pointed political background to the Board of Directors due to the experience, insight, and ability with regard to the government (Agrawal and Knoeber, 2001). A Board of Directors which has experience with regards to the government, considers that CSR can improve the performance of the company. According to Huang and Zhao (2016), political connections can be a positive correlation against the CSR performance of private companies listed on the Shanghai Stock Exchange for the period 2008-2014. In addition, political connections are considered capable of giving advantages to improve the company's performance (Bencheikh, et al., 2017) and also increase the value of the company (Faccio, 2006). Therefore, the second hypothesis in this research is as follows:

H2: Politically-connected Board is positively related to CSRD

\section{Sample and Research Model}

\subsection{Sample and Data}

We initially obtained from the Sustainability Disclosure Database a sample of 244 firm-year observations from Indonesia over the period 2013-2017 from the GRI database. To test our hypotheses, we exclude (1) firms that not listed on the Indonesia Stock Exchange; (2) firms that do not issue a sustainability report; (3) firms included in financial industries (SIC 6). The final sample consists of 110 firm-year observation with 33 firms. 
Our final data are described in Table I. Table I is comprised of firms' distribution by its connection. As shown in Panel A, we found that 28 firm-year observations ( 22 percent) from all our sample are of a military-connected firm. It means that, in only less than one-fourth of companies, one or more company board(s) has military experience. This result is consistent with other military connection research (Benmelech \& Frydman, 2015; Harymawan, 2018; Law \& Mills, 2017; Lin, et al., 2011) that military personnel and activities tend to be less certain in listed companies. This phenomenon is highlighted as a result of military-connected companies tending to be less transparent in order to avoid public monitoring (Misol, 2006). We also documented that, among all industry types based on US SIC only wholesale and trade industry (SIC 5), military-connected companies firmyear observations are higher than companies than do not have any military connection.

Table 1. Sample Distribution based on Industry Classification

\begin{tabular}{|c|c|c|c|c|c|c|}
\hline \multicolumn{7}{|c|}{ Panel A. Military Connection Sample Distribution (MCON) } \\
\hline \multirow{2}{*}{ Industry (SIC) } & \multicolumn{2}{|c|}{$\mathrm{MCON}$} & \multicolumn{2}{|c|}{ NON-MCON } & \multicolumn{2}{|c|}{ Total } \\
\hline & $\mathrm{N}$ & $\%$ & $\mathrm{~N}$ & $\%$ & $\mathrm{~N}$ & $\%$ \\
\hline $\begin{array}{c}\text { Agriculture, Forestry, and } \\
\text { Fishing }(0)\end{array}$ & 0 & 0 & 10 & 100 & 10 & 100 \\
\hline Mining and Construction (1) & 12 & 34 & 23 & 66 & 35 & 100 \\
\hline Manufacturing (2) & 6 & 40 & 9 & 60 & 15 & 100 \\
\hline Manufacturing (3) & 2 & 12 & 15 & 88 & 17 & 100 \\
\hline $\begin{array}{c}\text { Transportation, } \\
\text { Communications, Electric, } \\
\text { Gas and Sanitary service (4) }\end{array}$ & 1 & 5 & 19 & 95 & 20 & 100 \\
\hline Wholesale and Retail Trade & 7 & 78 & 2 & 22 & 9 & 100 \\
\hline Services (8) & 0 & 0 & 4 & 100 & 4 & 100 \\
\hline Total & 28 & 25 & 82 & 76 & 110 & 100 \\
\hline \multicolumn{7}{|c|}{ Panel B. Political Connection Distribution Sample (PCON) } \\
\hline \multirow{2}{*}{ Industry (SIC) } & \multicolumn{2}{|c|}{ PCON } & \multicolumn{2}{|c|}{ NON-PCON } & \multicolumn{2}{|c|}{ Total } \\
\hline & $\mathrm{N}$ & $\%$ & $\mathrm{~N}$ & $\%$ & $\mathrm{~N}$ & $\%$ \\
\hline $\begin{array}{c}\text { Agriculture, Forestry, and } \\
\text { Fishing }(0)\end{array}$ & 7 & 70 & 3 & 30 & 10 & 100 \\
\hline Mining and Construction (1) & 27 & 63 & 8 & 37 & 35 & 100 \\
\hline Manufacturing (2) & 10 & 80 & 5 & 20 & 15 & 100 \\
\hline Manufacturing (3) & 9 & 41 & 8 & 59 & 17 & 100 \\
\hline $\begin{array}{c}\text { Transportation, } \\
\text { Communications, Electric, Gas } \\
\text { and Sanitary service (4) }\end{array}$ & 16 & 75 & 4 & 25 & 20 & 100 \\
\hline Wholesale and Retail Trade (5) & 9 & 100 & 0 & 0 & 9 & 100 \\
\hline Services (8) & 2 & 50 & 2 & 50 & 4 & 100 \\
\hline Total & 73 & 66 & 37 & 34 & 110 & 100 \\
\hline
\end{tabular}

Source: Computed by authors

Unlike military connection, politically-connected companies have likely shown their presence in listed companies, as shown in panel B. According to our sample, there is 66 percent among all our sample classified as a politically-connected sample (see Table 2). It is also a fact that politically-connected boards are favored in 
Indonesia according to mounting research of Indonesia's political connections (Fisman, 2001; Habib, et al., 2017; Leux \& Oberholzer-Gee, 2006)..

Table 2. Sample Distribution based on Military and Political Connection Types

\begin{tabular}{|c|c|c|c|c|c|c|}
\hline \multicolumn{7}{|c|}{ Panel A. Military Connection Sample Distribution Types (MCON) } \\
\hline \multirow{2}{*}{ MCON Type } & \multicolumn{2}{|c|}{ Selected type MCON } & \multicolumn{2}{|c|}{ Other types MCON } & \multicolumn{2}{|c|}{ Total } \\
\hline & $\mathrm{N}$ & $\%$ & $\mathrm{~N}$ & $\%$ & $\mathrm{~N}$ & $\%$ \\
\hline \multicolumn{7}{|c|}{ Military position } \\
\hline Top officers (position) & 20 & 71 & 8 & 29 & 28 & 100 \\
\hline Middle officers (position) & 4 & 4 & 27 & 96 & 28 & 100 \\
\hline $\begin{array}{l}\text { Low officers and others } \\
\text { (position) }\end{array}$ & 7 & 25 & 21 & 75 & 28 & 100 \\
\hline \multicolumn{7}{|c|}{ Military origin } \\
\hline Army (Origin) & 18 & 64 & 10 & 36 & 28 & 100 \\
\hline Marine (Origin) & 7 & 25 & 21 & 75 & 28 & 100 \\
\hline Airforce (Origin) & 0 & 0 & 28 & 100 & 28 & 100 \\
\hline Police (Origin) & 7 & 25 & 21 & 75 & 28 & 100 \\
\hline \multicolumn{7}{|c|}{ Panel B. Political Connection Distribution Sample Types (PCON) } \\
\hline \multirow{2}{*}{ PCON Type } & \multicolumn{2}{|c|}{ Selected type PCON } & \multicolumn{2}{|c|}{ Other type PCON } & \multicolumn{2}{|c|}{ Total } \\
\hline & $\mathrm{N}$ & $\%$ & $\mathrm{~N}$ & $\%$ & $\mathrm{~N}$ & $\%$ \\
\hline \multicolumn{7}{|c|}{ Political board } \\
\hline Board of Commissioner & 78 & 96 & 2 & 4 & 80 & 100 \\
\hline Board of Director & 24 & 29 & 56 & 71 & 80 & 100 \\
\hline \multicolumn{7}{|c|}{ Political affiliation } \\
\hline $\begin{array}{c}\text { People's Consultative } \\
\text { Assembly }\end{array}$ & 17 & 21 & 63 & 79 & 80 & 100 \\
\hline House of Representatives & 15 & 19 & 65 & 81 & 80 & 100 \\
\hline Ministry & 71 & 89 & 9 & 11 & 80 & 100 \\
\hline Organization & 47 & 59 & 33 & 41 & 80 & 100 \\
\hline State-owned & 47 & 59 & 33 & 41 & 80 & 100 \\
\hline Political party & 0 & 0 & 80 & 100 & 80 & 100 \\
\hline
\end{tabular}

Interested in more types of military and political connection, we also classified our sample into more specific connections. Table 2 represents our sample with a more specific connection. We classify military connection into two classifications: based on military position and military origin (Panel A). There are three kinds of military positions which are a top officer (general), middle officer (major and colonel), and others. It shows that most of the military-connected boards have a high tier position with a former past military career. We also divide the military based on their origin. We add police origin as police (including Indonesian State Intelligence Agency personnel) as they mostly have the same traits as military personnel.

As for the political connection, we also classify this into two: based on its board position and its political affiliation (Panel B). It shows that politically-connected listed companies are dominated by a Politically Exposed Person (PEP) who has a connection to certain ministry in Indonesia ( 89 percent). 
Descriptive statistics are provided in Table 3, as shown below. We construct three panels of descriptive statistics with panel A using all sample $(\mathrm{N}=110)$, while panel $\mathrm{B}$ only focuses on the difference between military-connected $(\mathrm{N}=28)$ and non-military-connected sample $(\mathrm{N}=82)$ also panel $\mathrm{C}$ focuses on both politically connected $(\mathrm{N}=73)$ and non-politically-connected sample $(\mathrm{N}=37)$. Both panel $\mathrm{B}$ and $\mathrm{C}$ show that CSRD in military and political connections have greater average value compared to non-military and non-politically-connected sample, respectively.

Table 3. Statistic Descriptive

\begin{tabular}{|c|c|c|c|c|c|c|c|c|}
\hline \multicolumn{9}{|c|}{ Panel A. All Sample $(\mathrm{N}=110)$} \\
\hline Variable & \multicolumn{2}{|c|}{ Mean } & \multicolumn{2}{|c|}{ Median } & \multicolumn{2}{|c|}{ Minimum } & \multicolumn{2}{|c|}{ Maximum } \\
\hline CSRD & \multicolumn{2}{|c|}{0.401} & \multicolumn{2}{|r|}{0.357} & \multicolumn{2}{|c|}{0.099} & \multicolumn{2}{|c|}{0.956} \\
\hline MCON & \multicolumn{2}{|c|}{0.218} & \multicolumn{2}{|r|}{0.000} & \multicolumn{2}{|c|}{0.000} & \multicolumn{2}{|c|}{1.000} \\
\hline PCON & \multicolumn{2}{|c|}{0.664} & \multicolumn{2}{|r|}{1.000} & \multicolumn{2}{|c|}{0.000} & \multicolumn{2}{|c|}{1.000} \\
\hline ROE & \multicolumn{2}{|c|}{0.155} & \multicolumn{2}{|r|}{0.108} & \multicolumn{2}{|c|}{-0.406} & \multicolumn{2}{|c|}{1.358} \\
\hline LEV & \multicolumn{2}{|c|}{0.507} & \multicolumn{2}{|r|}{0.491} & \multicolumn{2}{|c|}{0.136} & \multicolumn{2}{|c|}{1.193} \\
\hline FSIZE & \multicolumn{2}{|c|}{30.701} & \multicolumn{2}{|r|}{30.771} & \multicolumn{2}{|c|}{28.453} & \multicolumn{2}{|c|}{32.744} \\
\hline BSIZE & \multicolumn{2}{|c|}{12.418} & \multicolumn{2}{|r|}{12.000} & & & & \\
\hline INDCOM & & 342 & & 0.333 & & & & \\
\hline AUDCOM & & 300 & & 3.000 & & & & \\
\hline BIG4 & & 300 & & 1.000 & & & & \\
\hline Panel B. Military C & $=28)$ and $\mathrm{I}$ & -Military Con & ction Sar & aple $(\mathrm{N}=82)$ & & & & \\
\hline & & ean & & Median & & num & & Ium \\
\hline Variable & MCON & Non-MCON & MCON & Non-MCON & MCON & $\begin{array}{c}\text { Non- } \\
\text { MCON }\end{array}$ & MCON & $\begin{array}{c}\text { Non- } \\
\text { MCON }\end{array}$ \\
\hline CSRD & 0.499 & 0.368 & 0.467 & 0.352 & 0.099 & 0.099 & 0.956 & 0.813 \\
\hline MCON_POS & 2.464 & 0.000 & 3.000 & 0.000 & 1.000 & 0.000 & 3.000 & 0.000 \\
\hline MCON_ARMY & 0.643 & 0.000 & 1.000 & 0.000 & 0.000 & 0.000 & 1.000 & 0.000 \\
\hline MCON_MARINE & 0.250 & 0.000 & 0.000 & 0.000 & 0.000 & 0.000 & 1.000 & 0.000 \\
\hline MCON_POLICE & 0.250 & 0.000 & 0.000 & 0.000 & 0.000 & 0.000 & 1.000 & 0.000 \\
\hline PCON & 0.929 & 0.659 & 1.000 & 1.000 & 0.000 & 0.000 & 1.000 & 1.000 \\
\hline ROE & 0.134 & 0.162 & 0.129 & 0.092 & -0.079 & -0.406 & 0.330 & 1.358 \\
\hline LEV & 0.511 & 0.506 & 0.502 & 0.491 & 0.281 & 0.136 & 0.744 & 1.193 \\
\hline FSIZE & 30.924 & 30.627 & 30.843 & 30.771 & 29.859 & 28.453 & 32.045 & 32.744 \\
\hline BSIZE & 12.571 & 12.366 & 12.000 & 12.000 & 9.000 & 7.000 & 20.000 & 17.000 \\
\hline INDCOM & 0.348 & 0.339 & 0.333 & 0.333 & 0.000 & 0.000 & 0.500 & 0.750 \\
\hline AUDCOM & 3.393 & 3.268 & 3.000 & 3.000 & 0.000 & 0.000 & 6.000 & 6.000 \\
\hline BIG4 & 0.607 & 0.866 & 1.000 & 1.000 & 0.000 & 0.000 & 1.000 & 1.000 \\
\hline
\end{tabular}


ISSN 2345-0282 (online) http://jssidoi.org/jesi/ 2019 Volume 7 Number 1 (September) http://doi.org/10.9770/jesi.2019.7.1(39)

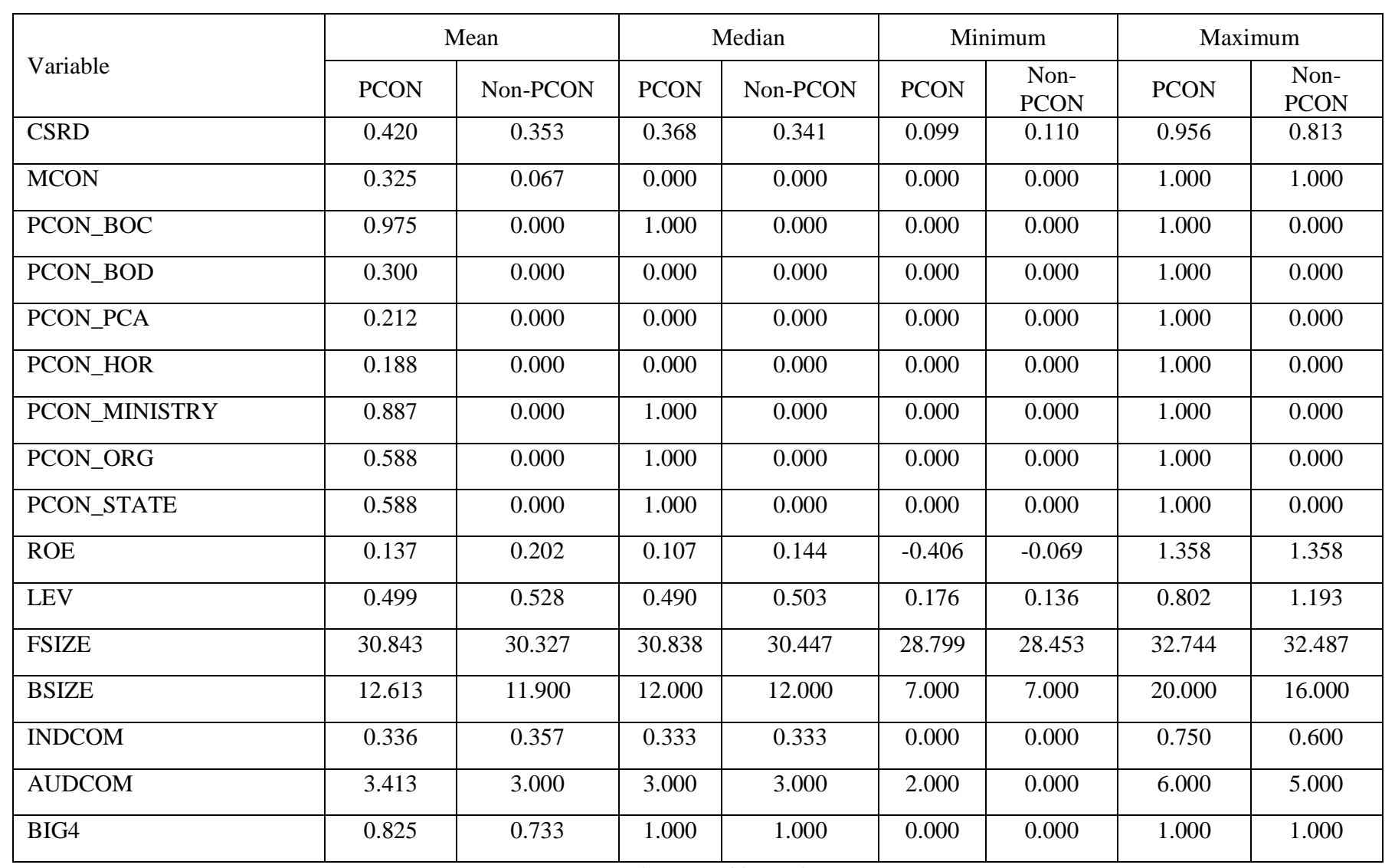

Source: Computed by authors

\subsection{Corporate Social Responsibility Disclosure (CSRD) Model}

To test the effect of military and political connections on the Corporate Social Responsibility Disclosure (CSRD), we estimate the following model:

$\operatorname{CSRD}_{i, t}=\beta_{0}+\beta_{1}$ MCON $_{i, t}+\beta_{2}$ PCON $_{i, t}+\beta_{3}$ ROE $_{i, t}+\beta_{4}$ LEV $_{i, t}+\beta_{5}$ FSIZE $_{i, t}+\beta_{6}$ BSIZE $_{i, t}+$ $\beta_{7} I N D C O M_{i, t}+\beta_{8} A U D C O M_{i, t}+\beta_{9} B I G 4_{i, t}+\beta_{10}$ YEAR $_{i, t}+\beta_{11} I_{N D U S T R Y}^{i, t}+\varepsilon_{i, t}$

We employed those control variables based on prior literature (Chen, et al., 2019; Martínez-Ferrero, et al., 2016; McGuinness, et al., 2017; Ramón-Llorensa, et al., 2018; Wang, et al., 2018 we add return on equity, leverage, firm's size, board of commissioners and directors, independent commissioners, audit committee, and firm's public accounting firm.

Table 4. Variable Definition

\begin{tabular}{|c|c|c|}
\hline Variable & Definition & Data source \\
\hline \multicolumn{3}{|l|}{ Dependent variable } \\
\hline CSRD & Percentage of disclosed criteria in Sustainability Report (SR) & SR \\
\hline \multicolumn{3}{|l|}{ Test variable } \\
\hline MCON_POS & $\begin{array}{l}\text { Military last position, } 3 \text { for top officers; } 2 \text { for middle officers; } 1 \text { for } \\
\text { lower officers and others and otherwise } 0\end{array}$ & ICMD \\
\hline
\end{tabular}




\section{ENTREPRENEURSHIP AND SUSTAINABILITY ISSUES}

ISSN 2345-0282 (online) http://jssidoi.org/jesi/ 2019 Volume 7 Number 1 (September) http://doi.org/10.9770/jesi.2019.7.1(39)

\begin{tabular}{|c|c|c|}
\hline MCON_ARMY & 1 for military origins is army (Angkatan Darat) and otherwise 0 & ICMD \\
\hline MCON_MARINE & 1 for military origins is marine (Angkatan Laut) and otherwise 0 & ICMD \\
\hline MCON_POLICE & $\begin{array}{l}1 \text { for military origins is police and/or Indonesian State Intelligence } \\
\text { Agency (Badan Intelijen Nasional) and otherwise } 0\end{array}$ & ICMD \\
\hline PCON & $\begin{array}{l}1 \text { for a firm with one or more commissioners and/or directors who } \\
\text { held political positions current/before sitting on the board and } \\
\text { otherwise } 0\end{array}$ & ICMD \\
\hline PCON_BOD & $\begin{array}{l}1 \text { for Political Exposed Person (PEP) is sitting on the Board of } \\
\text { Director and otherwise } 0\end{array}$ & ICMD \\
\hline PCON_PAC & $\begin{array}{l}1 \text { for Political Exposed Person (PEP) affiliation from People's } \\
\text { Consultative Assembly and otherwise } 0\end{array}$ & ICMD \\
\hline PCON_HOR & $\begin{array}{l}1 \text { for Political Exposed Person (PEP) affiliation from House of } \\
\text { Representatives and otherwise } 0\end{array}$ & ICMD \\
\hline PCON_STATE & $\begin{array}{l}1 \text { for Political Exposed Person (PEP) affiliation from state-owned } \\
\text { companies or Pemerintah Republik Indonesia (Indonesia's } \\
\text { government) ownership minimum } 10 \% \text { of total firm ownership and } \\
\text { otherwise } 0\end{array}$ & ICMD \\
\hline PCON_PARTY & $\begin{array}{l}1 \text { for Political Exposed Person (PEP) affiliation from a political party } \\
\text { and otherwise } 0\end{array}$ & ICMD \\
\hline \multicolumn{3}{|c|}{ 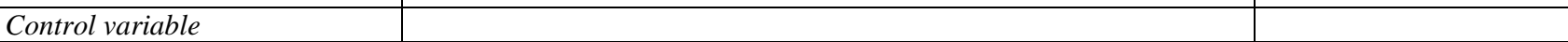 } \\
\hline ROE & Net income after preferred divided by average total assets for the year & OSIRIS \\
\hline LEV & Total liabilities scaled by total assets & OSIRIS \\
\hline FSIZE & Natural logarithm of total assets & OSIRIS \\
\hline BSIZE & The total person who sits on the boards & ICMD \\
\hline BIG4 & $\begin{array}{l}1 \text { for firm's Public Accountant Firm (PAF) is either Deloitte, Ernst \& } \\
\text { Young (EY), KPMG, and PricewaterhouseCoopers (PWC) and } \\
\text { otherwise } 0\end{array}$ & OSIRIS \\
\hline MILLS & The inverse Mills ratio & \\
\hline \multicolumn{3}{|l|}{ Selection model variable } \\
\hline MDIST & $\begin{array}{l}\text { Natural logarithm of the distance between the location of an } \\
\text { Indonesian Military base and the firm's headquarters }\end{array}$ & Mapdevelopers.com \\
\hline
\end{tabular}
Source: Constructed by authors

We provide operational variable measurement in Table 4. The data source of this research sample comes from Sustainability Report (SR), Indonesia Capital Market Directory (ICMD), OSIRIS database, Annual Report (AR) and map developer website. As mentioned before, we divide the military and political connection into a specific connection. We also derive other OLS to test the specific effect of each military connection and political connection on the CSRD. The estimated model for the specific connection types is:

$$
\begin{aligned}
& \operatorname{CSRD}_{i, t}=\beta_{0}+\beta_{1} X 1_{i, t}+\beta_{2} \text { ROE }_{i, t}+\beta_{3} L_{E V} V_{i, t}+\beta_{4} \text { FSIZE }_{i, t}+\beta_{5} \text { BSIZE }_{i, t}+\beta_{6} \text { INDCOM }_{i, t}+ \\
& \beta_{7} A_{U D C O M}{ }_{i, t}+\beta_{8} B I G 4_{i, t}+\beta_{9} Y_{E A R}{ }_{i, t}+\beta_{10} \operatorname{INDUSTRY~}_{i, t}+\varepsilon_{i, t} \\
& \operatorname{CSRD}_{i, t} \quad=\beta_{0}+\beta_{1} X 2_{i, t}+\beta_{2} \operatorname{ROE}_{i, t}+\beta_{3} \text { LEV }_{i, t}+\beta_{4} \text { FSIZE }_{i, t}+\beta_{5} \text { BSIZE }_{i, t}+\beta_{6} \text { INDCOM }_{i, t}+ \\
& \beta_{7} \text { AUDCOM }_{i, t}+\beta_{8} \text { BIG4 }_{i, t}+\beta_{9} \text { YEAR }_{i, t}+\beta_{10} \text { INDUSTRY }_{i, t}+\varepsilon_{i, t}
\end{aligned}
$$


$\mathrm{X} 1$ = Specific military connection types. It can be either military position or military origins (army, marine, police)

$\mathrm{X} 2$ = Specific political connection types. It can be either political board (board of commissioner, the board of director) or political affiliation (people's consultative assembly, house of representatives, organization, ministry, state, political party).

Table 5. Pearson Correlation Matrix $(\mathrm{N}=110)$

\begin{tabular}{|l|l|l|l|l|l|l|l|l|l|l|}
\hline & CSRD & MCON & PCON & ROE & LEV & FSIZE & BSIZE & INDCOM & AUDCOM & BIG4 \\
\hline CSRD & 1.000 & & & & & & & & & \\
\hline & & & & & & & & & & \\
\hline MCON & $0.366^{* * *}$ & 1.000 & & & & & & & & \\
\hline & $(0.000)$ & & & & & & & & & \\
\hline PCON & 0.018 & $0.376^{* * *}$ & 1.000 & & & & & & & \\
\hline & $(0.856)$ & $(0.000)$ & & & & & & & & \\
\hline ROE & -0.103 & -0.039 & -0.043 & 1.000 & & & & & & \\
\hline & $(0.286)$ & $(0.683)$ & $(0.653)$ & & & & & & & \\
\hline LEV & -0.137 & -0.071 & 0.105 & 0.082 & 1.000 & & & & & \\
\hline & $(0.153)$ & $(0.459)$ & $(0.275)$ & $(0.393)$ & & & & & & \\
\hline FSIZE & $0.239^{* *}$ & $0.161^{*}$ & $0.228^{* * *}$ & $-0.192^{* *}$ & -0.046 & 1.000 & & & & \\
\hline & $(0.012)$ & $(0.094)$ & $(0.017)$ & $(0.045)$ & $(0.631)$ & & & & & \\
\hline BSIZE & $0.310^{* * *}$ & 0.062 & 0.059 & 0.039 & -0.107 & $0.365^{* * *}$ & 1.000 & & & \\
\hline & $(0.001)$ & $(0.521)$ & $(0.543)$ & $(0.683)$ & $(0.264)$ & $(0.000)$ & & & & \\
\hline INDCOM & $0.209^{* *}$ & 0.044 & -0.074 & $-0.391^{* * *}$ & -0.136 & 0.133 & -0.100 & 1.000 & & \\
\hline & $(0.029)$ & $(0.648)$ & $(0.443)$ & $(0.000)$ & $(0.156)$ & $(0.165)$ & $(0.298)$ & & & \\
\hline AUDCOM & 0.022 & -0.095 & $0.181^{*}$ & -0.045 & -0.035 & $0.296^{* * *}$ & 0.045 & -0.041 & 1.000 & \\
\hline & $(0.820)$ & $(0.321)$ & $(0.059)$ & $(0.644)$ & $(0.718)$ & $(0.002)$ & $(0.640)$ & $(0.671)$ & & \\
\hline BIG4 & -0.069 & -0.121 & -0.067 & 0.141 & $-0.489^{* * *}$ & 0.099 & -0.062 & -0.094 & 0.038 & 1.000 \\
\hline & $(0.474)$ & $(0.208)$ & $(0.485)$ & $(0.143)$ & $(0.000)$ & $(0.304)$ & $(0.520)$ & $(0.328)$ & $(0.697)$ & \\
\hline
\end{tabular}

Table 5 provides a correlation matrix for all variables used in the main analyses. The relationship between MCON and CSRD is positive. We also found military connections are positively associated with the relationship between CSR and PCON variable is positive but not significant. This gives the picture that a company that has a member of the Board of Commissioners and/or Directors of connected politics will have no result on CSRD of the company. We also employ univariate test of our research variable. Table 6 displays the results of the t-test, which explains that the average value of the CSR performance of companies that have military connections is higher compared to companies that are not connected to the military, while the company connected politics has an average value of a company's CSRD higher than a company that without political connections. 
Table 6. Independent T-test Result

\begin{tabular}{|c|c|c|c|c|}
\hline \multicolumn{5}{|c|}{ Panel A. Military Connection Independent t-test (MCON) } \\
\hline VARIABLE & $\operatorname{MCON}(\mathrm{N}=24)$ & $\begin{array}{c}\text { NON-MCON } \\
(\mathrm{N}=86)\end{array}$ & Coef & t-value \\
\hline CSRD & 0.543 & 0.362 & $0.180^{* * *}$ & $4.093^{* * *}$ \\
\hline ROE & 0.132 & 0.161 & -0.028 & -0.410 \\
\hline BSIZE & 12.667 & 12.349 & 0.318 & 0.643 \\
\hline INDCOM & 0.352 & 0.339 & 0.013 & 0.458 \\
\hline AUDCOM & 3.125 & 3.349 & -0.224 & -0.997 \\
\hline BIG4 & 0.708 & 0.826 & -0.117 & -1.267 \\
\hline VARIABLE & $\operatorname{PCON}(\mathrm{N}=73)$ & NON-PCON $(\mathrm{N}=37)$ & Coef & t-value \\
\hline CSRD & 0.404 & 0.396 & 0.008 & 0.182 \\
\hline ROE & 0.145 & 0.173 & -0.027 & -0.451 \\
\hline LEV & 0.522 & 0.479 & 0.042 & 1.098 \\
\hline FSIZE & 30.853 & 30.402 & $0.451^{* *}$ & $2.435^{* *}$ \\
\hline BSIZE & 12.507 & 12.243 & 0.264 & 0.610 \\
\hline INDCOM & 0.335 & 0.355 & -0.019 & -0.770 \\
\hline AUDCOM & 3.425 & 3.054 & $0.371^{*}$ & $1.911^{*}$ \\
\hline BIG4 & 0.781 & 0.838 & -0.057 & -0.701 \\
\hline
\end{tabular}

\section{Empirical Results}

In this section, we reported the empirical result of research analysis on the relationship of military and political connection to Corporate Social Responsibility Disclosure (CSRD). In the first section, we provide the result of the OLS regression of the main research model. Next, we present the OLS regression for each relation of specific military and political connection to CSRD. Last but not least, we described the result of Heckman's two-stage regression model to deal with the military connection endogeneity problem.

\subsection{Main Analysis}

We provide our main analysis in Table 7. First, we decide to make the OLS regression model without any test variables (column 1) to find the adjusted $\mathrm{R}^{2}$ value before considering any test variables in the research model. In the second and third column, we provide each test variables (e.g. military connection and political connection), respectively. We found that military connection $(\mathrm{MCON})$ has a positive coefficient $(0.111)$ and is statistically significant at the 5 percent level $(\mathrm{t}=2.09)$. We also documented that the adjusted $\mathrm{R}^{2}$ value is increasing compared to first research model (column 1). Based on the third column, political connection (PCON) has no significant 
correlation ( $\mathrm{t}=0.94)$ on CSRD. We also employ both test variables into one research model and find MCON still has positive coefficient (0.108) and significant correlation $(\mathrm{t}=1.99)$, which implies that the result is robust in any model, with or without PCON in the research model. We also conduct the regression model where we make the interaction between MCON and PCON, but it shows no significant result.

Table 7. Military Connection, Political Connection and CSRD OLS

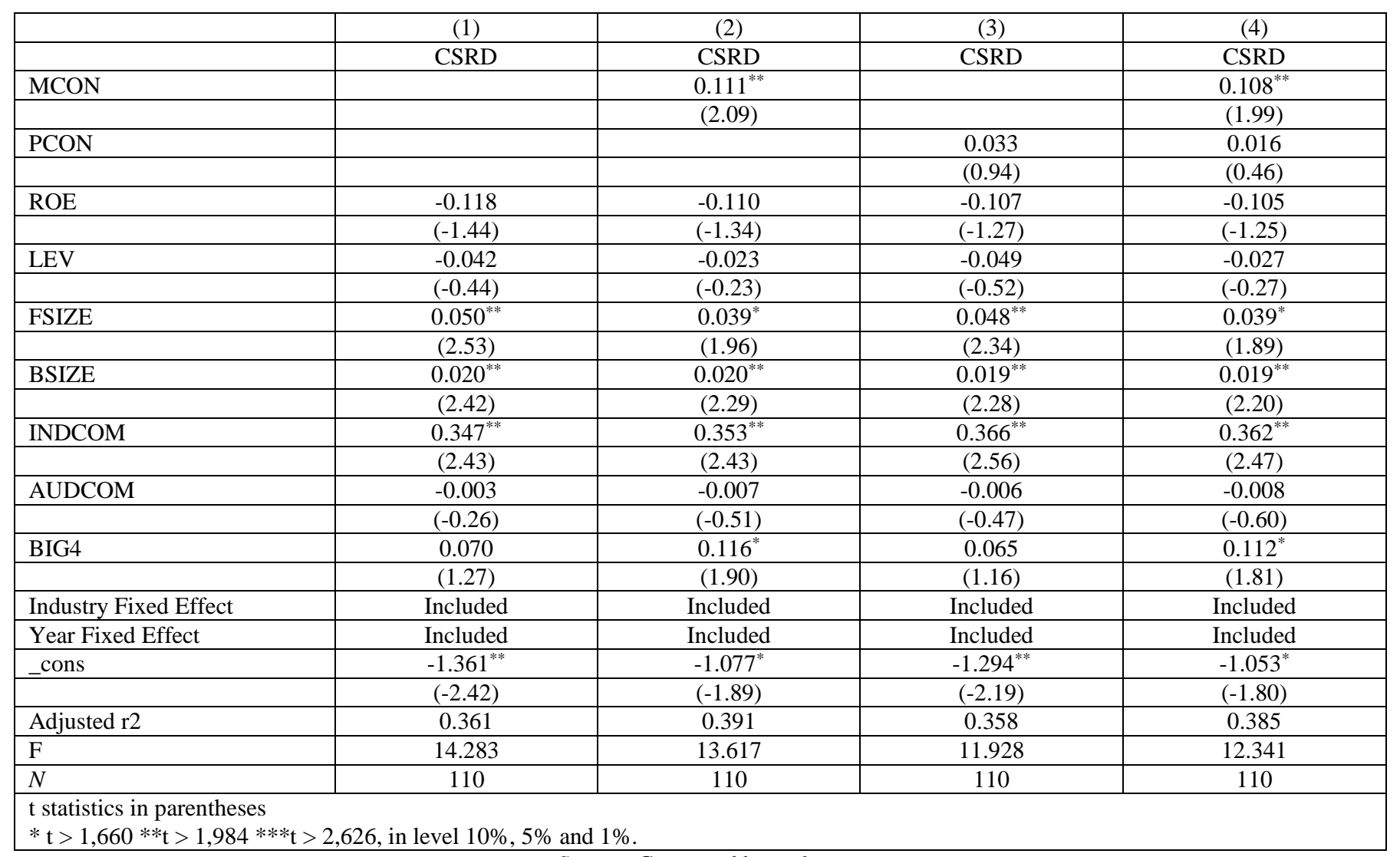

Source: Computed by authors

As MCON showing shows a positive correlation with CSRD, we infer that our first hypothesis is accepted while our second test variable, PCON, shows a different result. We expect that that result comes from the information disclosure of politically-connected firms as being lower compared to other firms. One of the reasons is that tendencies are politically-connected firms protect the benefits acquired from the political connection (Chaney, et al., 2011). Another possible reason is that the politically-connected board(s) will prioritize personal matter over firm interest (Bencheikh \& Taktak, 2017).

\subsection{Specific Military Connection Types Analysis}

In this section, we provide deeper analysis which specifies military connection types. As shown in Table 8 , we employ four additional specific military connection types (e.g. position, army, marine, and police). We omit the air force military origins as our sample did not consist of any air force military connection origins. The first column shows that the higher position of military career has a positive coefficient $(0.041)$ and significant correlation $(\mathrm{t}=2.16)$. Consistent with the military position, army and marine military connection are shown to be positive and statistically significant at level $1 \%$ and $5 \%$, respectively. The different result comes from a military 
connection that comes from police origin, it shows negative $(-0.228)$ correlation at a $1 \%$ level of significance ( $\mathrm{t}=-$ 3.24) with CSRD. These results also imply that the army and marine military origin correlations towards CSRD are stronger than police correlation as the aggregate military connection shows a positive correlation (Table 7).

Table 8. Military Connection, Political Connection and CSRD OLS

\begin{tabular}{|c|c|c|c|c|}
\hline & $(1)$ & $(2)$ & (3) & (4) \\
\hline & CSRD & CSRD & CSRD & CSRD \\
\hline MCON_POS & $(2.16)$ & & & \\
\hline MCON_ARMY & & $(2.65)$ & & \\
\hline \multirow[t]{2}{*}{ MCON_MARINE } & & & $0.200^{* * *}$ & \\
\hline & & & $(2.16)$ & \\
\hline \multirow[t]{2}{*}{ ROE } & -0.097 & -0.091 & -0.121 & -0.091 \\
\hline & $(-1.21)$ & $(-1.18)$ & $(-1.44)$ & $(-1.19)$ \\
\hline \multirow[t]{2}{*}{ LEV } & -0.008 & -0.002 & -0.054 & -0.041 \\
\hline & $(-0.08)$ & $(-0.02)$ & $(-0.57)$ & $(-0.45)$ \\
\hline FSIZE & $0.036^{*}$ & $0.034^{*}$ & $0.053^{* *}$ & $0.057^{* * * *}$ \\
\hline INDCOM & $(2.54)$ & $(2.35)$ & $(2.33)$ & $(2.23)$ \\
\hline \multirow[t]{2}{*}{ AUDCOM } & -0.002 & 0.001 & -0.003 & 0.007 \\
\hline & $(-0.18)$ & $(0.09)$ & $(-0.23)$ & $(0.53)$ \\
\hline \multirow[t]{2}{*}{ BIG4 } & $0.102^{*}$ & $0.093^{*}$ & 0.060 & 0.000 \\
\hline & $(1.84)$ & $(1.81)$ & $(1.12)$ & $(0.00)$ \\
\hline Industry Fixed Effect & Included & Included & Included & Included \\
\hline Year Fixed Effect & Included & Included & Included & Included \\
\hline \multirow[t]{2}{*}{ cons } & $-0.986^{*}$ & $-0.973^{*}$ & $-1.456^{* *}$ & $-1.616^{* * *}$ \\
\hline & $(-1.74)$ & $(-1.82)$ & $(-2.54)$ & $(-3.08)$ \\
\hline Adjusted r2 & 0.395 & 0.422 & 0.409 & 0.406 \\
\hline $\mathrm{F}$ & 13.922 & 14.440 & 14.524 & 16.187 \\
\hline$N$ & 110 & 110 & 110 & 110 \\
\hline
\end{tabular}

Source: Computed by authors

The military position is closely related to the number of responsibilities. A higher tier officer has more mounting responsibilities than their junior subordinates. This provides a basic understanding of the positive correlation between military position and CSRD. As for military origin, army and marine have been trained to possess Esprit De Corps and sensitivity to others, which means they feel responsible to help others in the form of corporate CSR. The negative correlation of police origins may come from the fact that police origin is dominated by the Indonesia State Intelligence Agency (Badan Intelijen Nasional), in which, although their organizational ultimate goal is to help others, most of their operations are conducted in secretly. They are not used to sharing information as most of the organizational activities are classified. 


\subsection{Specific Political Connection Types Analysis}

As we conducted with a military connection, we are also interested to further analyze the correlation of specific political connection types towards CSRD. Table 9 provides the result of specific political connection types. Among all specific political connection types only People's Consultative Assembly (MCON_PCA) and House of Representative (MCON_HOR) affiliation shows significant correlation towards CSRD. The coefficient MCON_PCA is 0.093 and MCON_HOR is 0.119 exposed 10\% $(\mathrm{t}=1.67)$ and $1 \%(\mathrm{t}=2.67)$ level of significance.

Table 9. Specific Political Connection OLS

\begin{tabular}{|c|c|c|c|c|c|c|c|}
\hline & (1) & (2) & (3) & (4) & (5) & (6) & (7) \\
\hline & CSRD & CSRD & CSRD & CSRD & CSRD & CSRD & CSRD \\
\hline PCON_BOC & $(1.34)$ & & & & & & \\
\hline PCON_BOD & & $(-1.38)$ & & & & & \\
\hline \multirow[t]{2}{*}{ PCON_PCA } & & & $0.093^{*}$ & & & & \\
\hline & & & $(1.67)$ & & & & \\
\hline \multirow[t]{2}{*}{ PCON_MINISTRY } & & & & & 0.017 & & \\
\hline & & & & & $(0.45)$ & & \\
\hline \multirow[t]{2}{*}{ PCON_ORG } & & & & & & 0.016 & \\
\hline & & & & & & $(0.48)$ & \\
\hline PCON_STATE & & & & & & & -0.000 \\
\hline LEV & $(-0.43)$ & $(-0.00)$ & $(-0.52)$ & $(-0.43)$ & $(-0.53)$ & $(-0.33)$ & $(-0.44)$ \\
\hline \multirow[t]{2}{*}{ FSIZE } & $0.048^{* * *}$ & $0.050^{* * *}$ & $0.043^{* * *}$ & $0.045^{* *}$ & $0.047^{* * *}$ & $0.049^{* * *}$ & $0.050^{* *}$ \\
\hline & $(2.40)$ & $(2.57)$ & $(2.26)$ & $(2.36)$ & $(2.09)$ & $(2.48)$ & $(2.42)$ \\
\hline \multirow[t]{2}{*}{ BSIZE } & $0.018^{* *}$ & $0.020^{* * *}$ & $0.020^{* * *}$ & $0.026^{* * * *}$ & $0.020^{* *}$ & $0.020^{* * *}$ & $0.020^{* *}$ \\
\hline & $(2.13)$ & $(2.51)$ & $(2.27)$ & $(3.01)$ & $(2.35)$ & $(2.36)$ & $(2.40)$ \\
\hline \multirow[t]{2}{*}{ INDCOM } & $0.365^{* *}$ & $0.331^{* * *}$ & $0.327^{* *}$ & $0.399^{* * *}$ & $0.349^{* * *}$ & $0.344^{* * *}$ & $0.347^{* *}$ \\
\hline & $(2.59)$ & $(2.38)$ & $(2.16)$ & $(2.83)$ & $(2.44)$ & $(2.40)$ & $(2.39)$ \\
\hline \multirow[t]{2}{*}{ AUDCOM } & -0.009 & -0.003 & -0.010 & -0.007 & -0.006 & -0.005 & -0.003 \\
\hline & $(-0.66)$ & $(-0.22)$ & $(-0.70)$ & $(-0.48)$ & $(-0.41)$ & $(-0.36)$ & $(-0.24)$ \\
\hline \multirow[t]{2}{*}{ BIG4 } & 0.069 & 0.065 & 0.060 & 0.060 & 0.067 & 0.069 & 0.070 \\
\hline & $(1.22)$ & $(1.26)$ & $(1.15)$ & $(1.15)$ & $(1.22)$ & $(1.26)$ & $(1.26)$ \\
\hline $\begin{array}{l}\text { Industry Fixed } \\
\text { Effect }\end{array}$ & Included & Included & Included & Included & Included & Included & Included \\
\hline cons & $(-2.24)$ & $(-2.43)$ & $(-2.02)$ & $(-2.42)$ & $(-1.90)$ & $(-2.36)$ & $(-2.28)$ \\
\hline Adjusted r2 & 0.364 & 0.374 & 0.379 & 0.395 & 0.355 & 0.355 & 0.354 \\
\hline $\mathrm{F}$ & 11.407 & 16.708 & 14.218 & 15.979 & 12.791 & 12.928 & 13.368 \\
\hline$N$ & 110 & 110 & 110 & 110 & 110 & 110 & 110 \\
\hline
\end{tabular}


The underlying reason behind those results is that both PCA and HOR are Indonesia's government bodies entitled to devise national regulations, including regulation related to CSR activities or its disclosure. It means PCA and HOR politically connected firms have a longer time to adjust to new regulations as, mostly, the firm will be informed long before those regulations are published.

\subsection{Self-selection Bias}

Self-selection bias is a bias that is introduced into a research project when participants choose whether or not to participate in the project, and the group that chooses to participate is not equivalent (in terms of the research criteria) to the group that opts out. The problem of selection bias in economic and social statistics and arises when a rule other than simple random sampling is used to sample the underlying population that is the object of interest (Heckman, 2010). According to Harymawan (2018), there are possibilities where unobserved military connection traits are the antecedents rather than military connections. In order to deal with this issue, we employ Heckman's two-stage model following Kim and Zhang (2016).

In the first stage of regression, we used military base distance (MDIST) as our selection model variable to ensure that the CSRD is correlated with the military connection, not the military base distance. Hereby, we estimate the following first stage regression model is as follows:

$\operatorname{MCON}_{i, t}=\beta_{0}+\beta_{1}$ MDIST $_{i, t}+\beta_{2} \operatorname{ROE}_{i, t}+\beta_{3}$ LEV $_{i, t}+\beta_{4}$ FSIZE $_{i, t}+\beta_{5}$ BSIZE $_{i, t}+\beta_{6}$ INDCOM $_{i, t}+$ $\beta_{7} \operatorname{AUDCOM}_{i, t}+\beta_{8}$ BIG4 $_{i, t}+\beta_{9}$ YEAR $_{i, t}+\beta_{10}$ INDUSTRY $_{i, t}+\varepsilon_{i, t}$

The exclusion variable in this research is MDIST, which is closely related to MCON. We believe that MDIST has no direct relationship to CSRD other than indirect impact through MCON. According to prior research (Harymawan, 2018; Kim \& Zhang, 2016), closer distance from firm headquarter office and military base will result in more chance of having military-connected board(s), at the same time that distance will have no explanation towards CSRD.

In order to examine the correlation between military connection and CSRD, we estimated the following secondlevel regression equation:

$$
\begin{array}{ll}
\text { CSRD }_{i, t} & \beta_{0}+\beta_{1} \text { MCON }_{i, t}+\beta_{2} \text { PCON }_{i, t}+\beta_{3} \text { ROE }_{i, t}+\beta_{4} \text { LEV }_{i, t}+\beta_{5} \text { FSIZE }_{i, t}+\beta_{6} \text { BSIZE }_{i, t}+ \\
& \beta_{7} \text { INDCOM }_{i, t}+\beta_{8} \text { AUDCOM }_{i, t}+\beta_{9} \text { BIG }_{i, t}+\beta_{10} \text { INVMILLS }_{i, t}+\beta_{11} \text { YEAR }_{i, t}+ \\
& \beta_{1} \text { INDUSTRY }_{i, t}+\varepsilon_{i, t}
\end{array}
$$

Using the estimation result of the first-level regression equation, we constructed Mills ratios and included these ratios in the second-stage regression (INVMILLS). The $\beta_{1}$ is expected to have positive and significant to indicate that military-connected board(s) will be favorable in terms of improving the CSRD.

Table 10. Heckman Two-Stage Regression

\begin{tabular}{|l|c|c|c|}
\hline & $\mathbf{1}^{\text {st }}$ Stage Regression & \multicolumn{2}{|c|}{$\mathbf{2}^{\text {st }}$ Stage Regression } \\
\hline & MCON & CSRD & CSRD \\
\hline MCON & & $0.101^{*}$ & $0.099^{*}$ \\
\hline PCON & & $(1.69)$ & $(1.66)$ \\
\hline & & & 0.014 \\
\hline MDIST & & & $(0.38)$ \\
\hline & $5.317^{* * * *}$ & & \\
\hline
\end{tabular}


ENTREPRENEURSHIP AND SUSTAINABILITY ISSUES

ISSN 2345-0282 (online) http://jssidoi.org/jesi/ 2019 Volume 7 Number 1 (September) http://doi.org/10.9770/jesi.2019.7.1(39)

\begin{tabular}{|c|c|c|c|}
\hline ROE & 0.072 & -0.111 & -0.106 \\
\hline & $(0.17)$ & $(-1.33)$ & $(-1.26)$ \\
\hline \multirow[t]{2}{*}{ LEV } & -0.359 & -0.012 & -0.017 \\
\hline & $(-0.46)$ & $(-0.11)$ & $(-0.16)$ \\
\hline \multirow[t]{2}{*}{ FSIZE } & $0.613^{* * * *}$ & 0.032 & 0.033 \\
\hline & $(2.61)$ & (1.10) & $(1.11)$ \\
\hline \multirow[t]{2}{*}{ BSIZE } & -0.091 & $0.022^{* *}$ & $0.021^{*}$ \\
\hline & $(-1.22)$ & $(2.00)$ & $(1.84)$ \\
\hline \multirow[t]{2}{*}{ INDCOM } & -1.008 & $0.371^{* *}$ & $0.376^{* *}$ \\
\hline & $(-0.90)$ & $(2.48)$ & $(2.50)$ \\
\hline \multirow[t]{2}{*}{ AUDCOM } & -0.166 & -0.007 & -0.008 \\
\hline & $(-1.16)$ & $(-0.49)$ & $(-0.57)$ \\
\hline \multirow[t]{2}{*}{ BIG4 } & $-1.551^{* * *}$ & $0.130^{*}$ & 0.125 \\
\hline & $(-3.45)$ & $(1.75)$ & $(1.61)$ \\
\hline \multirow[t]{2}{*}{ INVMILLS } & & -0.016 & -0.013 \\
\hline & & $(-0.35)$ & $(-0.28)$ \\
\hline Industry Fixed Effect & Included & Included & Included \\
\hline Year Fixed Effect & Included & Included & Included \\
\hline \multirow[t]{2}{*}{ _cons } & $-28.303^{* * *}$ & -0.876 & -0.890 \\
\hline & $(-3.50)$ & $(-1.07)$ & $(-1.08)$ \\
\hline Pseudo r2 & 0.301 & & \\
\hline Adjusted r2 & & 0.385 & 0.379 \\
\hline $\mathbf{F}$ & & 13.020 & 11.897 \\
\hline$N$ & 110 & 110 & 110 \\
\hline
\end{tabular}

Source: Computed by authors

Table 10 presents the result of Heckman's two-stage regression. The first column shows the result of the firststage regression model. It shows that military distance has positive (5.317) and significant correlation at $1 \%$ $(\mathrm{t}=4.25)$. The second and third column in Table 10 is the result of second-stage regression where the dependent is CSRD not MCON as in the first-stage regression. In the third column, we add PCON in the research model to provide a more robust result. This second-stage regression result implies that the correlation MCON toward CSRD is robust whether in ordinary OLS model (Table 8) or Heckman's two-stage regression model (Table 10).

\section{Conclusions}

Based on the test results of the analysis performed over the variables examined, the conclusions that can be drawn from this study are as follows. Military connection has positive and significant effect against CSR, meaning the company having a member of the Board of Commissioners or Directors of the experienced military can generate CSR better than companies that do not have a Member the Board of Commissioners or Directors who are military experienced. This is because members of the military are known as the soul of good leadership, discipline, and also the ability of good organizing (Harymawan, 2018) , as well as having influence in management decision-making (Benmelech \& Frydman, 2015), considered to be able to improve performance as well as the CSRD of company. However, political connections have a negative and not significant relationship towards CSR. This is due to the possibility of an indication that members of the Board of Commissioners or Directors of connected politics would sacrifice the interests of the company for the sake of objective political connections for personal gain (Bencheikh \& Taktak, 2017), so that attention to managing your company's information disclosure quality will be low in order to protect the benefits obtained on gains from political connections (Chaney, et al., 2011). For further studies we recommend that to add more proxy of CSR such as 


\section{ENTREPRENEURSHIP AND SUSTAINABILITY ISSUES}

ISSN 2345-0282 (online) http://jssidoi.org/jesi/ 2019 Volume 7 Number 1 (September)

http://doi.org/10.9770/jesi.2019.7.1(39)

KLD (Simpson \& Sariol, 2018), CSR advertising expense (Oh, et al., 2017) or other CSRD criteria to provide more robust result of military connection and CSR correlation.

\section{References}

Abd Rahman, I. \& Ku Ismail, K. N. I., 2016. The effects of political connection on corporate social responsibility disclosure - evidence from listed companies in Malaysia. International Journal of Business and Management Invention 5(2): 16-21. Retrieved from https://www.researchgate.net/publication/303402635_The_effects_of_political_connection_on_corporate_social_responsibility_disclosure _-_evidence_from_listed_companies_in_Malaysia

Bencheikh, F. \& Taktak, N. B., 2017. The effect of political connections on the firm performance in a newly democratised country. Mediterranean Journal of Social Sciences 8(4): 40-46. https://doi.org/10.1515/mjss-2017-0004

Benmelech, E. \& Frydman, C., 2015. Military CEOs. Journal of Financial Economics 117(1): 43-59. https://doi.org/10.3386/w19782

Bertrand, M., Kramarz, F., Schoar, A. \& Thesmar, D., 2018. The cost of political connections. Review of Finance, pp. 849-876. https://doi.org/10.1093/rof/rfy008

Chaney, P. K., Faccio, M. \& Parsley, D., 2011. The quality of accounting information in politically connected firms. Journal of Accounting and Economics 51(1-2): 58-76. http://dx.doi.org/10.2139/ssrn.966379

Chen, W., Zhou, G. \& Zhu, X., 2019. CEO tenure and corporate social responsibility performance. Journal of Business Research 95: 292302. https://doi.org/10.1016/j.jbusres.2018.08.018

Duffy, T., 2006. Military experience and CEOs: Is There a Link?, s.1.: Kom/Ferry International Report. Retrieved form https://www.kornferry.com/institute/190-military-experience-and-ceos-is-there-a-link

Elder, G., 1986. Military times and turning points in men's lives. Developmental Psychology 22(2): 233-245. https://doi.org/10.1037/0012$\underline{1649.22 .2 .233}$

Elder, G. \& Clipp, E., 1989. Combat experience and emotional health: Impairment and resilience in later life. Journal of Personality 57(2): 311-341. https://doi.org/10.1111/j.1467-6494.1989.tb00485.x

Faisal, Barid, B. \& Mulyanto, D., 2018. Pendanaan Partai Politik di Indonesia: Mencari Pola Pendanaan Ideal untuk Mencegah Korupsi. Integritas 4(1): 265-287. https://doi.org/10.32697/integritas.v4i1.248

Fernandez-Feijoo, B., Romero, S. \& Ruiz, S., 2014. Commitment to Corporate social responsibility measured through global reporting initiative reporting: factors affecting the behavior of companies. Journal of Cleaner Production 81. 244-254.

https://doi.org/10.1016/j.jclepro.2014.06.034

Fisman, R., 2001. Estimating the Value of Political Connections. American Economic Review 91(4): 1095-1102.

https://doi.org/10.1257/aer.91.4.1095

Fung, S., Gul, F. \& Radhakrishnan, S., 2015. Corporate political connections and the 2008 Malaysian election. Accounting, Organization, and Society 43(3): 67-86. https://doi.org/10.1016/j.aos.2015.04.001

Funnel, W., 2005. Accounting on the frontline: cost accounting, military efficiency, and the South African war. Accounting and Business Research, 35(4): 307-326. https://doi.org/10.1080/00014788.2005.9729997

Göktepe, G. \& Satyanath, S., 2013. The economic value of military connections in Turkey. Public Choice: 531-552. https://doi.org/10.1007/s11127-011-9886-8 


\section{ENTREPRENEURSHIP AND SUSTAINABILITY ISSUES}

ISSN 2345-0282 (online) http://jssidoi.org/jesi/ 2019 Volume 7 Number 1 (September)

http://doi.org/10.9770/jesi.2019.7.1(39)

Groysberg, B., Hill, A. \& Johnson, T., 2010. Which of these people is your future CEO? The different ways military experience prepares managers for leadership. Harvard Business Review: 81-85. Retrieved from https://hbr.org/2010/11/which-of-these-people-is-your-futureceo-the-different-ways-military-experience-prepares-managers-for-leadership

Habib, A., Muhammadi, A. \& Jiang, H., 2017. Political connections, related party transactions, and auditor choice: Evidence from Indonesia. Contemporary Accounting Research: 1-19. https://doi.org/10.1016/j.jcae.2017.01.004

Harymawan, I., 2018. Why do firms appoint former military personnel as directors? Evidence of loan interest rate in militarily connected firms in Indonesia. Asian Review of Accounting 26(1): 2-18. https://doi.org/10.1108/ARA-07-2016-0086

Heckman, J., 2010. Selection Bias and Self-Selection. In: Microeconometrics. London: Palgrave Macmillan: 242-266. https://doi.org/10.1057/9780230280816_29

Hermawan, A., Aisyah, I. S., Gunardi, A. \& Putri, W. Y., 2018. Going Green: Determinants of Carbon Emission Disclosure in Manufacturing Companies in Indonesia. International Journal of Energy Economics and Policy, 8(1), pp. 55-61. Retrieved from https://www.econjournals.com/index.php/ijeep/article/view/6009

Huang, H. \& Zhao, Z., 2016. The influence of political connection on corporate social responsibility_evidence from Listed private companies in China. International Journal of Corporate Social Responsibility: 9-28. https://doi.org/10.1186/s40991-016-0007-3

Human Rights Watch, 2006. Indonesia: Military Business Threatens Human Rights, s.l.: Scoop Media Limited. Retrieved from https://www.hrw.org/news/2006/06/21/indonesia-military-business-threatens-human-rights

Kaoe, E. H., Yeh, C.-C., Wang, L.-H. \& Fung, H.-G., 2018. The relationship between CSR and performance: Evidence in China. PacificBasin Finance Journal 51: 155-170. https://doi.org/10.1016/i.pacfin.2018.04.006

Kim, C. \& Zhang, L., 2016. Corporate Political Connections and Tax Aggressiveness. Contemporary Accounting Research 33(1): 78-114. https://doi.org/10.1111/1911-3846.12150

Law, K. K. F. \& Mills, L. F., 2017. Military experience and corporate tax avoidance. Review of Accounting Studies 22(1): 141-184. https://doi.org/10.1007/s11142-016-9373-Z

Law, K. K. \& Mills, L. F., 2015. Managerial Characteristics and Corporate Taxes. Colloquium On Tax Policy And Public Finance Spring 2015. Retrieved from https://www.law.nyu.edu/sites/default/files/upload_documents/Lillian\%20Mills.pdf

Law, K. \& Mills, L. F., 2013. Following the Rules? Corporate Tax Reporting by CEOs with Military Experience. SSRN Electronic Journal https://doi.org/10.2139/ssrn.2302329

Oberholzer-Gee, F. \& Leux, C., 2006. Political relationships, global financing, and corporate transparency: Evidence from Indonesia. Journal of Financial Economics 81(2): 411-439. http://dx.doi.org/10.2139/ssrn.720741

Leuz, C., Nanda, D. \& Wysocki, P. D., 2003. Earnings management and investor protection: an international comparison. Journal of Financial Economics, 69(3), pp. 505-527. http://dx.doi.org/10.1016/S0304-405X(03)00121-1

Lin, C., Ma, Y., Officer, M. S. \& Zou, H., 2011. CEOs' military experience, agency costs and acquisition decisions. SSRN Electronic Journal. http://dx.doi.org/10.2139/ssrn.1932623

Lin, K., Mills, L., Zhang, F. \& Li, Y., 2018. Do Political Connections Weaken Tax Enforcement Effectiveness?. Contemporary Accounting Research: 1941-1972. https://doi.org/10.1111/1911-3846.12360

Martínez-Ferrero, J., Rodríguez-Ariza, L. \& García-Sánchez, I.-M., 2016. Corporate social responsibility as an entrenchment strategy, with a focus on the implications of family ownership. Journal of Cleaner Production 135: 760-770.

https://doi.org/10.1016/i.jclepro.2016.06.133 


\section{ENTREPRENEURSHIP AND SUSTAINABILITY ISSUES}

ISSN 2345-0282 (online) http://jssidoi.org/jesi/ 2019 Volume 7 Number 1 (September)

http://doi.org/10.9770/jesi.2019.7.1(39)

McChesney, F. S., 1987. Rent extraction and rent creation in the economic. The Journal of Legal Studies: 179-196.

https://doi.org/10.1086/467825

McGuinness, P. B., Vieito, J. P. \& Wang, M., 2017. The role of board gender and foreign ownership in the CSR performance of Chinese listed firms. Journal of Corporate Finance 42: 75-99. https://doi.org/10.1016/j.jcorpfin.2016.11.001

Mietzner, M., 2009. Military Politics, Islam, and the State in Indonesia: from Turbulent Transition to Democratic Consolidation. Singapore: Institute of Southeast Asian Studies https://doi.org/10.1355/9789812308450

Mietzner, M., 2015. Dysfunction by Design: Political Finance and Corruption in Indonesia. Critical Asian Studies: 587-610. https://doi.org/10.1080/14672715.2015.1079991

Mietzner, M. \& Misol, L., 2012. Military businesses in post-Suharto Indonesia: decline, reform, and persistence. In: The Politics of Military Reform. Berlin and Heidelberg: Springer, pp. 101-120. https://doi.org/10.1007/978-3-642-29624-6_5

Misol, L., 2006. Too high a price: the human rights cost of the Indonesian military's economic activities, s.l.: Human Right Watch. Retrieved from https://www.hrw.org/report/2006/06/20/too-high-price/human-rights-cost-indonesian-militarys-economic-activities

Oh, H., Bae, J. \& Kim, S. J., 2017. Can Sinful Firms Benefit from Advertising Their CSR Efforts? Adverse Effect of Advertising Sinful Firms' CSR Engagements on Firm Performance. Journal of Business Ethics 134(4): 643-663. https://doi.org/10.1007/s10551-016-3072-3

O'Keefe, B., 2010. Battle-tested: how a decade of war has created a new generation of elite business leaders. Human Resource Management International Digest 18(6). https://doi.org/10.1108/hrmid.2010.04418fad.006

Porta, R., Lopez-de-Silanes, F., Shleifer, A. \& Vishny, R. W., 1997. Legal determinants of external finance. The Journal of Finance 52(3): 1131-1150. https://doi.org/10.3386/w5879

Ramón-Llorensa, M. C., García-Mecaa, E. \& Pucheta-Martínez, M. C., 2018. The role of human and social board capital in driving CSR reporting. Long Range Planning. https://doi.org/10.1016/j.lrp.2018.08.001

Rieffel, A. \& Pramodhawardani, J., 2007. Out of Business and on Budget: The Challenge of Military Financing in Indonesia. MA and Washington, DC: Brookings Institution Press, 356p.

Shah, A., 2014. Constraining consolidation: military politics and democracy in Pakistan (2007-2013). Democratization 21(6): 1007-1033. https://doi.org/10.1080/13510347.2013.781586

Simpson, J. \& Sariol, A. M., 2018. Squared Away: Veterans on the Board of Directors. Journal of Business Ethics, pp. 1-11. https://doi.org/10.1007/s10551-018-3907-1

Vestergaard, T., 2006. Government Sets Up Agency to Manage Military-Run Indonesian Businesses, s.1.: Global Insight Daily Analysis.

Wang, Z., Reimsbach, D. \& Braam, G., 2018. Political embeddedness and the diffusion of corporate social responsibility practices in China: A trade-off between financial and CSR performance?. Journal of Cleaner Production 198: 1185-1197.

https://doi.org/10.1016/i.jclepro.2018.07.116

Wong, L., Bliese, P. \& McGurk, D., 2003. Military leadership: a context-specific review. Leadership Quarterly 14: 657-692.

https://doi.org/10.1016/j.leaqua.2003.08.001

\section{Aknowledgements}

This research has received funding from the Tahir World Class Professorship 


\section{ENTREPRENEURSHIP AND SUSTAINABILITY ISSUES}

ISSN 2345-0282 (online) http://jssidoi.org/jesi/ 2019 Volume 7 Number 1 (September)

http://doi.org/10.9770/jesi.2019.7.1(39)

Mohammad NASIH is the Professor of Department of Accounting, Faculty of Economics and Business, Universitas Airlangga, Indonesia. Currently he is rector of Universitas Airlangga for period 2015 - 2020. He obtained his Doctoral degree (2005) in accounting from Universitas Airlangga in Indonesia, Master degree (1997) in Industry Technology from Institut Teknologi Bandung in indonesia, Bachelor degree (1991) in accounting from Universitas Airlangga in Indonesia. Research interest: islamic accounting; financial accounting

ORCID ID: orcid.org/0000-0002-7945-7593

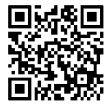

Iman HARYMAWAN is an Assistant Professor in the Department of Accounting, Faculty of Economics and Business, Universitas Airlangga, Indonesia. He obtained his PhD degree (2016) in accounting from City University of Hong Kong in Hong Kong, MBA degree (2009) from National Cheng Kung University in Taiwan, and his B.A. degree (2006) in accounting from Universitas Airlangga in Indonesia. His current research focuses include: corporate governance issues, the accounting impact of political and military connections in business, and financial reporting quality. He currently teaches financial reporting analysis, managerial accounting, and advanced accounting. Research interest: board connection; corporate governance, management accounting

ORCID ID: orcid.org/0000-0001-7621-6252

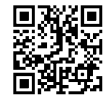

Fajar Kristanto Gautama PUTRA is master student in accounting from Universitas Airlangga in Indonesia. He obtained his bachelor degree (2018) in accounting from Universitas Airlangga. He currently works as reseach assistant in Center of Politic, Economic, and Business Research (CPEBR), a researcher grup that operates under Faculty of Economics and Business, Universitas Airlangga, Indonesia. Research interest: human resources disclosure; sustainability reporting

ORCID ID: orcid.org/0000-0003-1213-0593

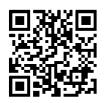

Rizka QOTRUNNADA just graduated from Airlangga Universtiy, Indonesia for her bachelor degree in accounting. Previously, she had studied at Airlangga University, Indonesia for her associate degree in accounting too. Research interest: sustainability reporting; corporate governance; financial accounting; taxation

ORCID ID: orcid.org/0000-0002-9864-0596

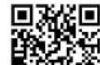

Register for an ORCID ID: https://orcid.org/register

Copyright (C) 2019 by author(s) and VsI Entrepreneurship and Sustainability Center

This work is licensed under the Creative Commons Attribution International License (CC BY).

http://creativecommons.org/licenses/by/4.0/

(c) (i) Open Access 